\title{
Impact of nano-ZnO/grafted textile on the outer membrane permeability of some pathogenic bacteria
}

\author{
M B EL-ARNAOUTY ${ }^{1}$, M EID $^{1, *}$ and S Y EL TABLAWY ${ }^{2}$ \\ ${ }^{1}$ Polymer Chemistry Department, National Center for Radiation Research and Technology (NCRRT), \\ Atomic Energy Authority, P.O. Box 29, Nasr City, Egypt \\ ${ }^{2}$ Department of Drug Radiation Research, National Center for Radiation Research and Technology (NCRRT), \\ Atomic Energy Authority, P.O. Box 29, Nasr City, Egypt \\ *Author for correspondence (mona_eid2000@yahoo.com)
}

MS received 7 March 2016; accepted 10 February 2017; published online 15 September 2017

\begin{abstract}
Cotton textile grafted by chitosan hydroxyethyl methacrylate has been prepared by gamma radiation as a polymeric stabilizer for $\mathrm{ZnO}$ nanoparticles (NPs). The grafting percent and swelling property of the prepared grafted polymer in bi-distilled water were studied and the results showed that the swelling percent of the plain textile is higher than that of all different compositions. The morphology and structure of plain textile, grafted textile and nano- $\mathrm{ZnO} /$ grafted textile were examined by scanning electron microscopy (SEM) and Fourier transform infrared spectroscopy (FT-IR). The presence of $\mathrm{ZnO}$ in the prepared samples was examined by energy-dispersive X-ray spectroscopy (EDX) and X-ray diffraction (XRD). The particle size of the formed ZnO NPs has been estimated by transmission electron microscopy (TEM). The results indicate the nanoscale of the $\mathrm{ZnO}$ particles. Nano-ZnO/grafted textile was tested against some pathogenic strains, and the results show that the nano- $\mathrm{ZnO} /$ grafted textile was able to attenuate bacterial growth of MRSA and Klebsiella pneumoniae after $24 \mathrm{~h}$ of direct contact. Also, release of potassium ions, loss of absorbing materials and decrease of membrane surface potential were noticed, indicating alteration of cell membrane permeability. Furthermore, SEM observation showed bacterial cell deformation for growth on the nano- $\mathrm{ZnO} /$ grafted textile. These results have been promising in the antibacterial field.
\end{abstract}

Keywords. Textile; chitosan; HEMA; ZnO nanoparticles; FTIR; pathogenic bacteria.

\section{Introduction}

There has been a great deal of attention in recent years given to the hazards of microbial contamination from potential everyday exposure, especially in hospitals (nosocomial infection). A wide range of bacteria, fungi and viral pathogens are responsible for such infections. A rapid and uncontrolled multiplication of these pathogenic microbes can seriously compromise health and hygienic living standards. One potential method for reducing the occurrence and spread of nosocomial infections is the use of antimicrobial textiles. Textiles of all varieties are considered to be very proficient at carrying bacteria and serving as a reservoir for the transmission of infection [1]. Textiles from natural fibres such as cotton are also well known to be more susceptible to microorganisms than synthetic fibres because they are capable of easily holding water, oxygen and nutrients, providing a favourable environment for bacterial growth [2]. Therefore, antimicrobial textiles may be of great help in the recovery process of transplant patients, people with immunodeficiency diseases, low-immunity patients and premature babies [1]. Two different aspects of antimicrobial protection provided by chemical finishes can be distinguished. The first is the protection of the textile user against pathogenic or odour-causing microorganisms. The second is the protection of the textile fibres itself, from degradation [3]. Chitosan exhibits excellent biological properties; it is nontoxic, biocompatible and biodegradable [4]. For its exceptional features, chitosan has received interest in various fields.

Inorganic materials such as metal oxides attracted a great attention over the past decade owing to their ability to withstand harsh process conditions $[5,6]$. Organic materials and metal oxides such as $\mathrm{TiO}_{2}, \mathrm{ZnO}, \mathrm{MgO}$ and $\mathrm{CaO}$ are of special interest as they are not only stable under harsh process conditions but also generally regarded as safe materials to human beings and animals [5,7]. Nanoparticles (NPs) with their large surface area to volume ratio have been studied as likely candidates for antimicrobial agents. The antimicrobial activity has been observed to vary as a function of surface area in contact with the microbe; therefore, NPs with large surface area ensure a broad range of reactions with the bacterial surface [8]. Metal oxide NPs with antimicrobial activity, when embedded and coated on to surfaces, can find immense applications in numerous fields such as water treatment, cosmetics, synthetic textiles, biomedical and surgical devices [9]. These inorganic NPs kill bacteria through various mechanisms, e.g., binding to intracellular proteins and inactivating them, generation of reactive oxygen and via direct damage to cell walls [10]. Microbes are more unlikely to develop resistance against 
NPs since they attack a broad range of targets, which requires the microorganism to develop defence mechanisms.

Nano-ZnO/grafted textiles have become quite common $[11,12]$. To our knowledge, the efficiency of $\mathrm{ZnO} \mathrm{NP}$ in imparting antibacterial effect to fabric is not yet well established although it is known to have a strong resistance to microorganisms [12]. ZnO NP is currently being investigated as an antibacterial agent both against Gram-negative microorganisms such as Escherichia coli and Gram-positive microorganisms such as Staphylococcus aureus in microscale and nanoscale formulations [13]. An important aspect of the use of $\mathrm{ZnO}$ as antibacterial agent is the requirement that the particles are not toxic to human cells $[14,15]$.

In the present work a simple method is suggested to develop a medical fabric using nano- $\mathrm{ZnO} /$ cotton textile grafted by chitosan/2-hydroxyethylmethacrylate (HEMA) [textile-g-(chitosan/HEMA)] using gamma radiation to evaluate the antibacterial properties and the proposed mechanism of action of this antibacterial agent. The prepared polymeric nanocomposites were evaluated by infrared (FT-IR) spectroscopy, scanning electron microscopy (SEM), energydispersive X-ray spectroscopy (EDX), X-ray diffraction (XRD) and transmission electron microscopy (TEM).

\section{Experimental}

\subsection{Chemicals}

HEMA of purity 99\% (Merck, Germany) was used as received. Chitosan [molecular weight 100,000-300,000, $\left(\mathrm{C}_{6} \mathrm{H}_{11} \mathrm{NO}_{4}\right)_{n}$ ] was obtained from Acros Organics (New Jersey, USA, and Geel, Belgium). ZnO NP (Mw $81.39 \mathrm{~g} \mathrm{~mol}^{-1}$, powder NP size $<50 \mathrm{~nm}$ ) was obtained from Sigma-Aldrich (Germany).

\subsection{Preparation of nano-ZnO/[textile-g-(chitosan/HEMA)]}

Aqueous solutions of $2 \%$ chitosan and 50\% HEMA were mixed in different ratios of (chitosan/HEMA) - (20:80), $(40: 60),(50: 50),(60: 40)$ and $(80: 20)$. The mixtures were poured into test tubes of diameter $15 \mathrm{~mm}$ containing $6 \times 5 \mathrm{~cm}^{2}$ textile samples of known weight and irradiated with gamma rays using a cobalt-60 source at radiation dose of $20 \mathrm{kGy}$. After irradiation, the grafted textile samples were washed thoroughly with hot distilled water and soaked overnight in water to extract the residual monomer and homopolymer. The samples were then dried in a vacuum oven at $40^{\circ} \mathrm{C}$ for $24 \mathrm{~h}$ and weighed. The degree of grafting (\%) was determined by the percentage increase in weight as follows:

$$
\text { Grafting }(\%)=\left[\left(W_{\mathrm{g}}-W_{\mathrm{o}}\right) / W_{\mathrm{o}}\right] \times 100,
$$

where $W_{\mathrm{o}}$ and $W_{\mathrm{g}}$ represent the weight of ungrafted and grafted sample, respectively.
To prepare nano-ZnO/textile-g-(chitosan/HEMA), the grafted textile samples were immersed in different concentration of aqueous $\mathrm{ZnO}$ solution for $24 \mathrm{~h}$, dried and stored for later use.

\subsection{Swelling studies}

For swelling studies, pre-weighed grafted textile samples were immersed into bi-distilled water. Swollen grafted textile sample were removed from water at regular intervals and dried superficially with filter paper, weighed and placed in the same bath. Swelling (\%) was calculated as follows:

$$
\text { Swelling }(\%)=\left[\left(W_{\mathrm{s}}-W_{\mathrm{o}}\right) / W_{\mathrm{o}}\right] \times 100 \text {, }
$$

where $W_{\mathrm{s}}$ is the weight of the swollen grafted textile and $W_{\mathrm{o}}$ is the weight of initial dry sample.

\subsection{Characterization}

FT-IR of grafted textile samples was performed according to ASTM E 1252-(02) 'Standard Practice for General Techniques for Obtaining Infrared Spectra using Perkin-Elmer Spectrum One (USA)' in the range $400-4000 \mathrm{~cm}^{-1}$. A scanning electron microscope (JEOL-JSM-5400, Japan) was used for investigating the surface morphology of the plain, grafted and nano-ZnO/grafted textile samples at a high magnification and resolution by means of an energetic electron beam. EDX measurements of nano-ZnO/grafted textile samples were characterized using an EDX (Oxford, England)-ISIS attached to a SEM-JEOL-5400 with voltage of $20 \mathrm{keV}$. The XRD method was used to identify the ZnO NPs in the grafted textile nanocomposites. These measurements were carried out using a Shimadzu X-ray diffractometer (XRD-6000 model) equipped with an X-ray tube $[\mathrm{Cu}$ target, $40 \mathrm{kV}$ (voltage), $30 \mathrm{~mA}$ (current)]. The X-ray data were recorded in the $2 \theta$ range $4-90^{\circ}$ (degree) with continuous scanning mode and scanning speed $8^{\circ} \mathrm{min}^{-1}$. A transmission electron microscope (TEM) was used to image the $\mathrm{ZnO}$ nanocomposites. Finely ground nano- $\mathrm{ZnO} /$ grafted textile samples were dispersed in $1 \mathrm{ml}$ of ethanol followed by sonication to get a solution of $\mathrm{ZnO}$ NPs. Approximately 10-20 $\mu \mathrm{l}$ of this solution was dropped on a $3 \mathrm{~mm}$ copper grid and dried at room temperature. The copper grid was inserted into the TEM.

\subsection{Microbiological studies}

A total of 20 preliminary identified clinical isolates (5Staphylococcus spp., 5 Escherichia coli, 5 Klebsiella spp., 3 Pseudomonas spp., 1 Bacillus sp. and 1 Candida sp.) were obtained from the Drug Microbiology Laboratory, Drug Radiation Research Department. Cultures were grown on nutrient agar (NA) plates and Sabouraud-Dextrose agar (SDA) for Candida sp. and maintained in the agar slants at $4{ }^{\circ} \mathrm{C}$. The antibacterial activity of nano- $\mathrm{ZnO} /$ grafted textile with different concentrations of $\mathrm{ZnO}$ was tested qualitatively and quantitatively. 
Qualitative assessment of antibacterial activity was assayed using the disk diffusion method as described by Ophori and Wemabu [16]. Briefly, a small single isolated colony was emulsified in $2 \mathrm{ml}$ sterile nutrient broth (NB) or SabouraudDextrose broth (SDB) and incubated at $37^{\circ} \mathrm{C}$ for $3 \mathrm{~h}$. Sterile cotton swabs with the suspensions were used to evenly spread the entire surface of Mueller-Hinton agar plates to obtain uniform inocula. The plates were dried for 2-4 min. Discs $(5 \mathrm{~mm}$ diameter) of the plain, the grafted and the nano- $\mathrm{ZnO} /$ grafted textile samples (pre-sterilized by autoclaving at $121^{\circ} \mathrm{C}$ for $15 \mathrm{~min}$ ) were gently pressed onto the surface of the plate. The plates were incubated at $37^{\circ} \mathrm{C}$ for $24 \mathrm{~h}$. The antibacterial activity of the tested fabrics was demonstrated by the diameter of the zone of inhibition in comparison with the plain one. The experiment was performed in duplicate and the mean value was taken. The most susceptible isolates were identified according to their macroscopic and microscopic morphology and genetically identified by ribosomal ribonucleic acid (rRNA). To study the molecular identification, bacterial whole genomes were extracted using a Wizard genomic DNA isolation kit (\#A1120, Promega Corporation, USA). Bacterial identification by PCR and direct sequencing of 16S rRNA gene were performed according to [17], using forward $8 \mathrm{~F}$ primer ' 5 ' AGA GTT TCC TGG CTC AG' and reverse U1492R primer '5'GGT TAC CTT GTT ACG ACT T'. It was applied in Centre of Virology, Faculty of Agriculture, Cairo University.

Quantitative measurement of antibacterial activity was carried out according to the AATCC Test Method [18]. The tested textile disc was placed in a sterile screw-capped tube; $100 \mu \mathrm{l}$ of $10^{6} \mathrm{CFU} \mathrm{ml}{ }^{-1}$ from the different tested bacterial strains was loaded on it with even distribution of the inocula. At different time intervals (2, 4, 6 and $24 \mathrm{~h}), 900 \mu \mathrm{l}$ of sterile distilled water was added and mixed by shaking for $1 \mathrm{~min}$. After that, 10-fold dilutions in sterile distilled water were made. From each dilution, $100 \mu \mathrm{l}$ was surface inoculated on NA plates. Then, the plates were incubated at $37^{\circ} \mathrm{C}$ for $24 \mathrm{~h}$. Colonies were counted and the reduction percent $(R \%)$ was calculated using the following equation:

$$
R(\%)=(B-A) \times 100 / B
$$

where $A$ is the number of bacterial colonies from the treated disc after the contact period and $B$ is the number of bacterial colonies from plain discs at zero contact time.

\subsection{Microbiological assays}

To estimate the potassium ion leakage, overnight NB cultures of the tested cells were centrifuged and the cells were washed three times by deionized water. Then, the cells were re-suspended in $5 \mathrm{ml}$ of sterilized deionized water and treated with discs of nano- $\mathrm{ZnO} /$ grafted textile. They were incubated at $37^{\circ} \mathrm{C}$ for 30,60 and $120 \mathrm{~min}$ and the levels of $\mathrm{K}^{+}$ions were measured using a photometer (Alfa Wasserman Style 111, $\mathrm{Na}^{+}, \mathrm{K}^{+}, \mathrm{Cl}^{-}$analyser). Flasks with plain discs were tested similarly. Results were expressed as the amount of extracellular free potassium $\left(\mathrm{mmol} \mathrm{l}^{-1}\right)$ in the growth media in each interval of incubation period [19]. To measure the release of $260 \mathrm{~nm}$ absorbing material from cells treated by plain textile and nano- $\mathrm{ZnO} /$ grafted textile discs, the discs were added to $2 \mathrm{ml}$ of $18 \mathrm{~h}$ bacterial culture in sterile peptone water. After incubation at $35^{\circ} \mathrm{C}$ for 2,4 and $6 \mathrm{~h}$, cells were centrifuged at 3,500 rpm and the optical densities (ODs) of the supernatants were measured spectrophotometrically using a JASCO V 560 UV-VIS spectrophotometer at $260 \mathrm{~nm}$ to observe the bacterial cell damage.

The surface charge of the cells under study was evaluated and measured as zeta potential. The zeta potential of bacterial cultures, treated with plain textile discs or with nano$\mathrm{ZnO}$ /grafted textile discs, was measured using a Nano Zeta Potential/Particle Sizer NICOMP ${ }^{\mathrm{TM}} 380$ ZLS PSS (Nicomp Particle Sizing System, Santa Barbara, California, USA). Briefly, $100 \mu \mathrm{l}$ of the bacterial culture was freshly inoculated in $5 \mathrm{ml}$ of $\mathrm{MHB}$ and incubated at $37^{\circ} \mathrm{C}$ for $360 \mathrm{~min}$, where final bacterial concentration of $\approx 1.1 \times 10^{9} \mathrm{CFU} \mathrm{ml}{ }^{-1}$ was reached ( 0.4 at OD 590). The bacterial suspensions were then centrifuged at 10,000 rpm (20 min), the supernatant was discarded and the cell pellets were washed five times with $0.5 \mathrm{mM}$ potassium phosphate buffer solution $(\mathrm{pH} 7.4)$. The bacterial cell suspension was prepared by re-suspending the
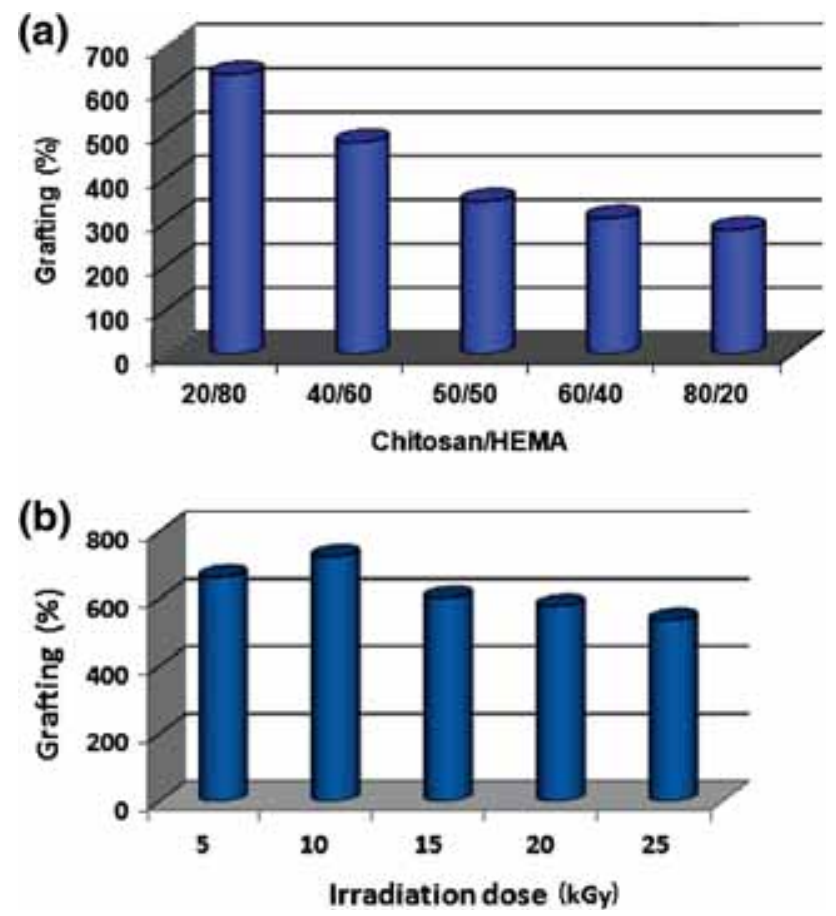

Figure 1. (a) Effect of copolymer composition on the grafting (\%) of textile-g-(chitosan/HEMA) prepared by gamma irradiation at $20 \mathrm{kGy}$. (b) The effect of irradiation dose on the grafting (\%) of textile-g-(chitosan/HEMA) (50:50). 
cell pellet in the used buffer. The OD 590 of the final dispersion varied between 0.12 and 0.15 ; then the washed bacterial cell suspension was incubated with discs of nano-ZnO/grafted textiles and incubated for $1 \mathrm{~h}$ at room temperature prior to zeta potential measurements. For the positive control, the washed bacterial cell pellets were incubated at the same conditions without nano-ZnO treatment [20]. For SEM study, plain textile and nano-ZnO/grafted textile discs were placed on NA plates seeded with $100 \mu \mathrm{l}$ of the tested strain. The plates were incubated at $37^{\circ} \mathrm{C}$ for $24 \mathrm{~h}$; later small parts of the discs were cut, directly coated using a gold sputter coater and examined using A JEOL-JSM-5400 (Japan) scanning electron microscope.

\section{Results and discussion}

Figure $1 \mathrm{a}$ and $\mathrm{b}$ shows the effect of copolymer composition and irradiation dose on the grafting (\%) of textile-g(chitosan/HEMA) prepared by gamma radiation. As shown
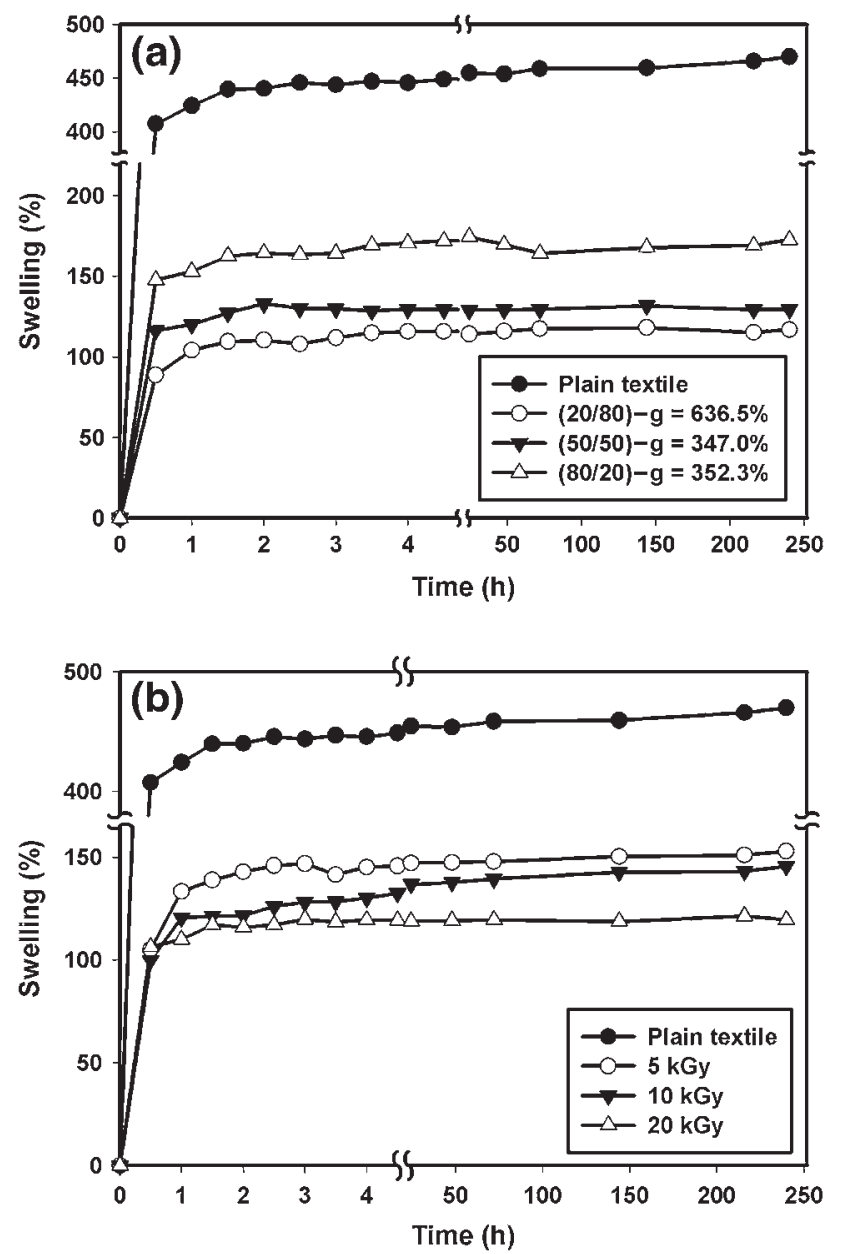

Figure 2. (a) Effect of copolymer composition on the swelling (\%) of textile-g-(chitosan/HEMA) prepared by gamma irradiation $20 \mathrm{kGy}$. (b) The effect of irradiation dose on the swelling (\%) of textile-g-(chitosan/HEMA) (50:50). in figure 1a, the copolymer composition significantly influences the degree of grafting $(\%)$ of the grafted textile. It is clear from the figure that the grafting percentage highly increases by increasing HEMA content. The afore-mentioned results could be explained in the light of increasing of vinyl groups present in the copolymer that was prepared with a high content of HEMA [21]. This may be due to the higher diffusivity of the HEMA into the textile matrix compared with that of chitosan. Also the grafting process of (chitosan/HEMA) copolymer composition may be enhanced in the presence of HEMA due to its higher polarity strength than that of chitosan [22].

The effect of the irradiation dose on the grafting (\%) of textile-g-(chitosan/HEMA) is shown in figure 1b. From the figure it can be noticed that the grafting (\%) increases at irradiation dose of $10 \mathrm{kGy}$. This may be due to an increase in the number of free radicals formed, which increases the diffusion rate of copolymer into the textile matrix, thus increasing the grafting yield [23]. It was also noticed that at irradiation doses higher than $10 \mathrm{kGy}$, the degree of grafting $(\%)$ decreased; this is due to the increase of the free

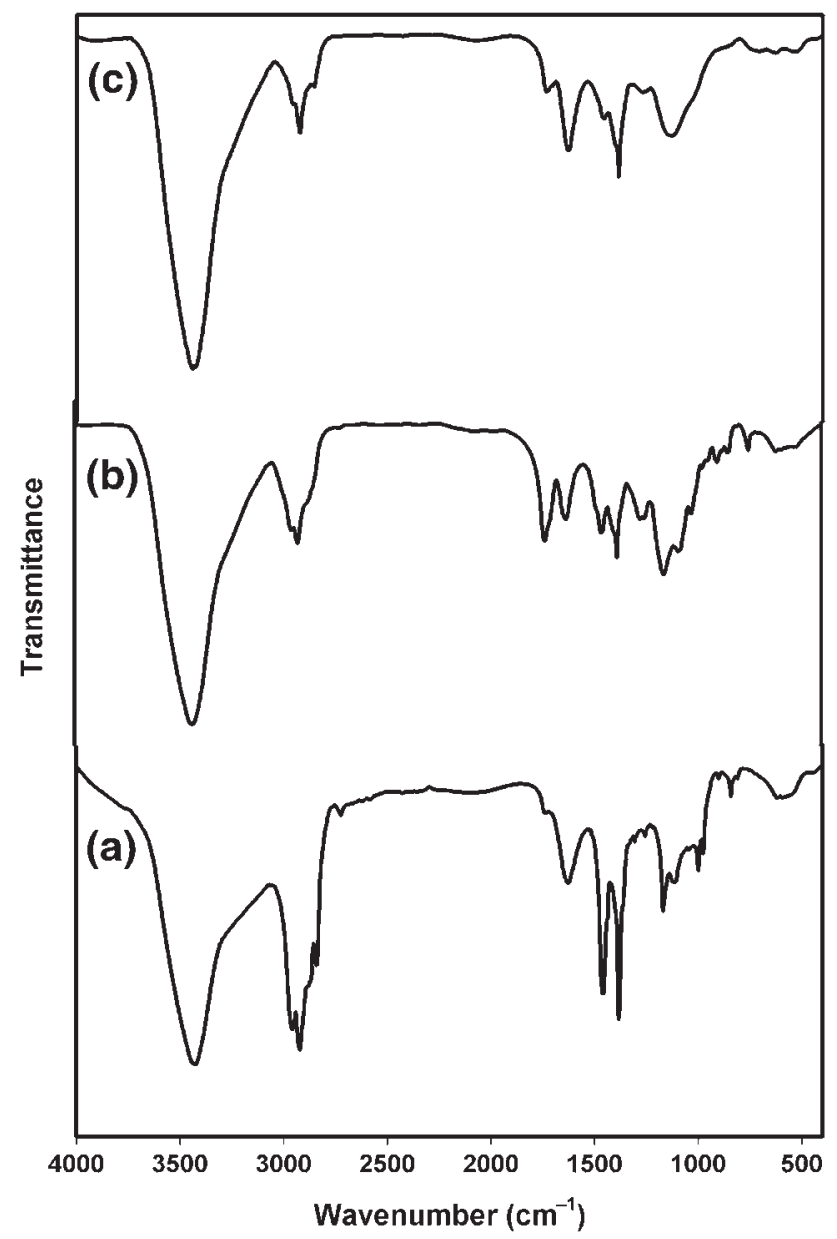

Figure 3. FTIR spectra of (a) plain textile, (b) textile-g(chitosan/HEMA) and (c) nano-ZnO/grafted textile at $20 \mathrm{kGy}$. 
radicals numbers, which leads to recombination of the free radicals with each other and the rapid formation of the homopolymer rather than the diffusion into the textile matrix [24].

\subsection{Swelling study}

When a grafted textile is brought into contact with water, the solution diffuses into the network and a volume phase transition occurs, resulting in the expansion of the grafted textile. Diffusion involves the migration of fluid into the grafted textile or dynamically formed spaces between the grafted textile chains. Swelling of the grafted textile involves a large segmental motion, resulting, ultimately, in the increased separation of the grafted textile chains [25]. The effect of the copolymer composition on the swelling percent is presented in figure $2 \mathrm{a}$. It can be seen that the swelling behaviour of the grafted textile is greatly influenced by its composition. The figure shows that the swelling percent of grafted textile decrease by increasing HEMA content in the feed mixture. It would hold the network perfectly by increasing the crosslinking density as the free radicals increase it also resulted in the narrowing of pore size and reduce the free space available for water retention [26].

It is well known that the degrees of grafting and crosslinking greatly depend on the irradiation dose. Higher exposure dose means a longer exposure time, which consequently prolongs the propagation step of the process of copolymerization leading to higher degrees of conversion and crosslinking. The effect of irradiation dose on the swelling of grafted textile is shown in figure $2 \mathrm{~b}$. From the figure, it is found that the swelling (\%) decreases as the irradiation dose increases, which may be due to the increasing of the crosslinking percentage in the grafted textile. As a result, a reduction of the free volume available for swelling by increasing the tightness of the network structure will happen.

\subsection{Characterization}

Compositional and structural information concerning plain textile, textile-g-chitosan/HEMA and nano-ZnO/grafted textile samples has been investigated by FTIR spectroscopy. Spectra of different samples are shown in figure $3 a-c$. In the
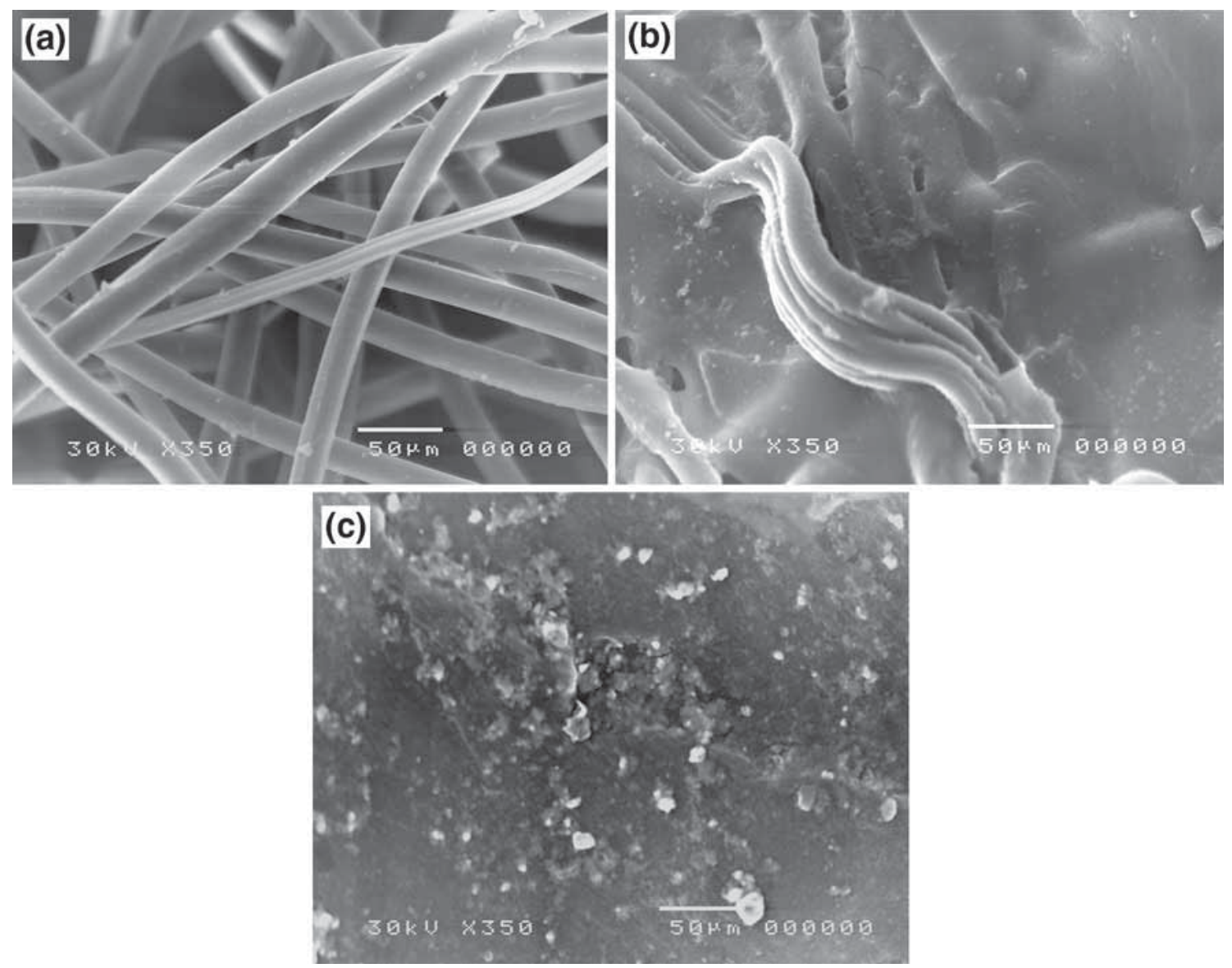

Figure 4. SEM images of (a) plain textile, (b) textile-g-(chitosan/HEMA) (50:50) and (c) nano-ZnO/grafted textile at $20 \mathrm{kGy}$. 


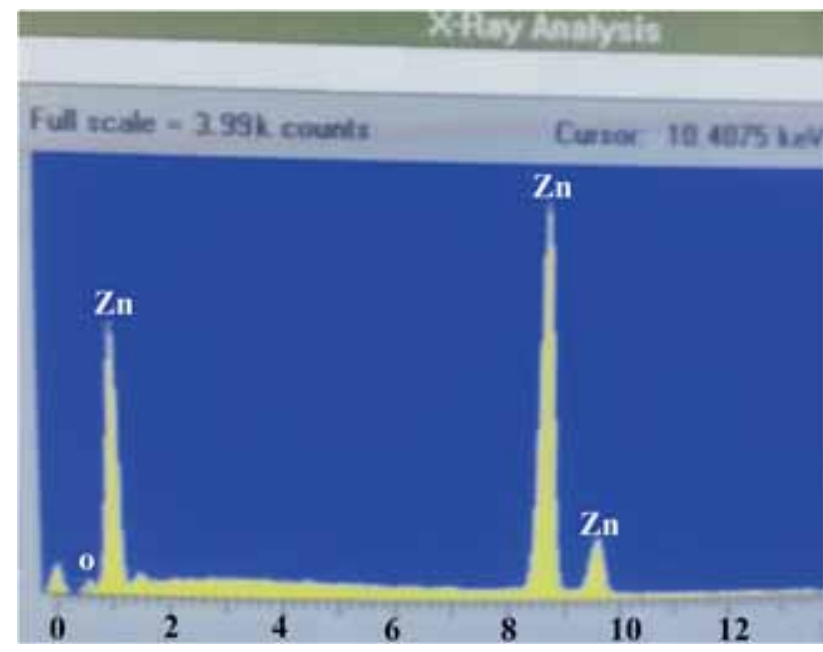

Figure 5. EDX measurement of nano- $\mathrm{ZnO} /$ grafted textile at $20 \mathrm{kGy}$.

spectra of plain textile (figure 3a), the characteristic absorptions that appear at 1156,1081 and $1019 \mathrm{~cm}^{-1}$ are attributed to the $\mathrm{C}-\mathrm{O}-\mathrm{C}$ stretching vibration of the anhydroglucose of cellulose units. The band at $2930 \mathrm{~cm}^{-1}$ is characteristic of the $\mathrm{CH}_{3}$ stretching vibration and the bands at 2850 and $1457 \mathrm{~cm}^{-1}$ are attributed to $\mathrm{CH}_{2}$ [27-29]. Figure 3b, of textile-g-(chitosan/HEMA) spectrum, shows absorption bands for the $\mathrm{C}=\mathrm{O}$ stretching, and $\mathrm{N}-\mathrm{H}$ bending of the amide bands appears at $1623 \mathrm{~cm}^{-1}$. The regions of absorption peaks for the N-H stretching of the primary amide appear at 3197 and $3446 \mathrm{~cm}^{-1}$. In addition, the peak at $1400 \mathrm{~cm}^{-1}$ is for the $-\mathrm{C}-\mathrm{N}$ stretching, and at $750 \mathrm{~cm}^{-1}$ is for the weak band $\mathrm{N}-\mathrm{H}$ out-of-plane bending. As shown in figure $3 \mathrm{c}$, the interaction of $\mathrm{ZnO}$ NPs with grafted textile results in the decrease of the band intensity of $\mathrm{OH}$ and $\mathrm{NH}$ and also in the absorption band of $\mathrm{C}=\mathrm{O}$ [30].

Figure $4 a, b$ and c shows the SEM of the plain textile, the textile-g-(chitosan/HEMA) and the nano-ZnO/grafted textile, respectively. The apparent physical nature of the plain textile, as seen in figure $4 \mathrm{a}$, shows the smooth fibrous network. Figure $4 \mathrm{~b}$ shows the crosslinking copolymer formed within the plain textile network. The resulting polymer forms a coating of the fibres as shown in the figure, which reveals that the surface is not smooth and many wrinkles are observed. This is probably due to structural rearrangement on the chains of functional groups [23]. It can be seen from figure $4 \mathrm{c}$ that the $\mathrm{ZnO}$ NPs are observed and have a spherical particle shape. The SEM image of ZnO NPs shows that the final products exhibited aggregation as a result of surface modification by the attachment of the grafted polymer.

The presence of $\mathrm{ZnO}$ in the textile-g-(chitosan/HEMA) can be determined by EDX analysis as supporting information, confirming the presence of $\mathrm{ZnO}$ in the grafted textile. Figure 5 presents the EDX curves of nano-ZnO/grafted textile. From the figure it can be clearly noticed that EDX analysis confirms the existence of $\mathrm{Zn}$ and $\mathrm{O}$ peaks of $\mathrm{ZnO}$ in the grafted textile.
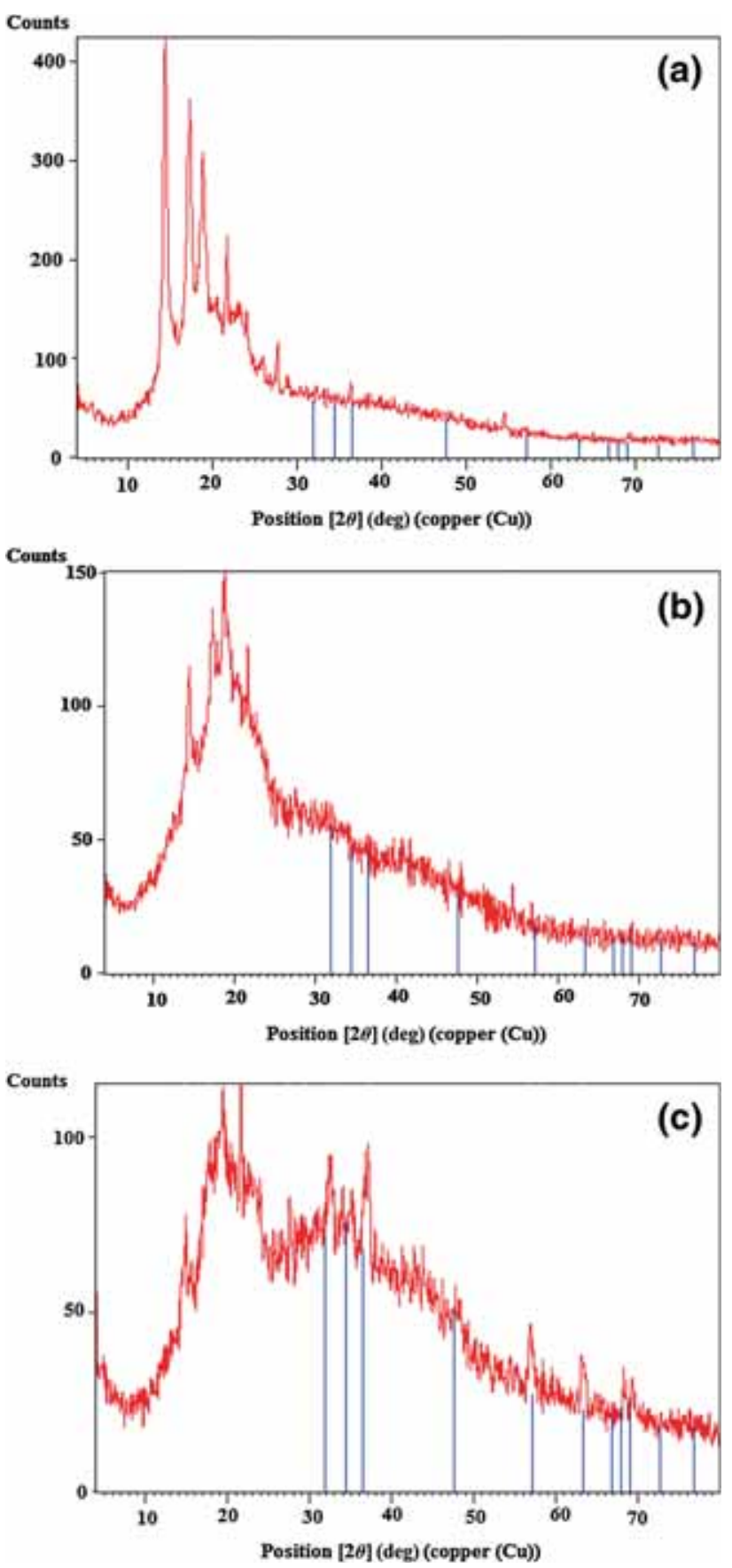

Figure 6. XRD of (a) plain textile, (b) textile-g-(chitosan/HEMA) (50:50) and (c) nano-ZnO/grafted textile at $20 \mathrm{kGy}$.

The XRD data of plain textile, textile-g-(chitosan/HEMA) and nano- $\mathrm{ZnO} /$ grafted textile are discussed to investigate some features, namely the degree of ordering and crystallite size. XRD analysis was performed also to confirm the crystal phase of ZnO NPs embedded grafted textile. Figure $6 a-c$ shows the typical XRD pattern for the specimen. The observed peak around $2 \theta$ value of $20^{\circ}$ corresponds to the amorphous nature of the plain textile and textile-g-(chitosan/HEMA) (figure $6 a, b)$. It was noted that the grafting process for textile 

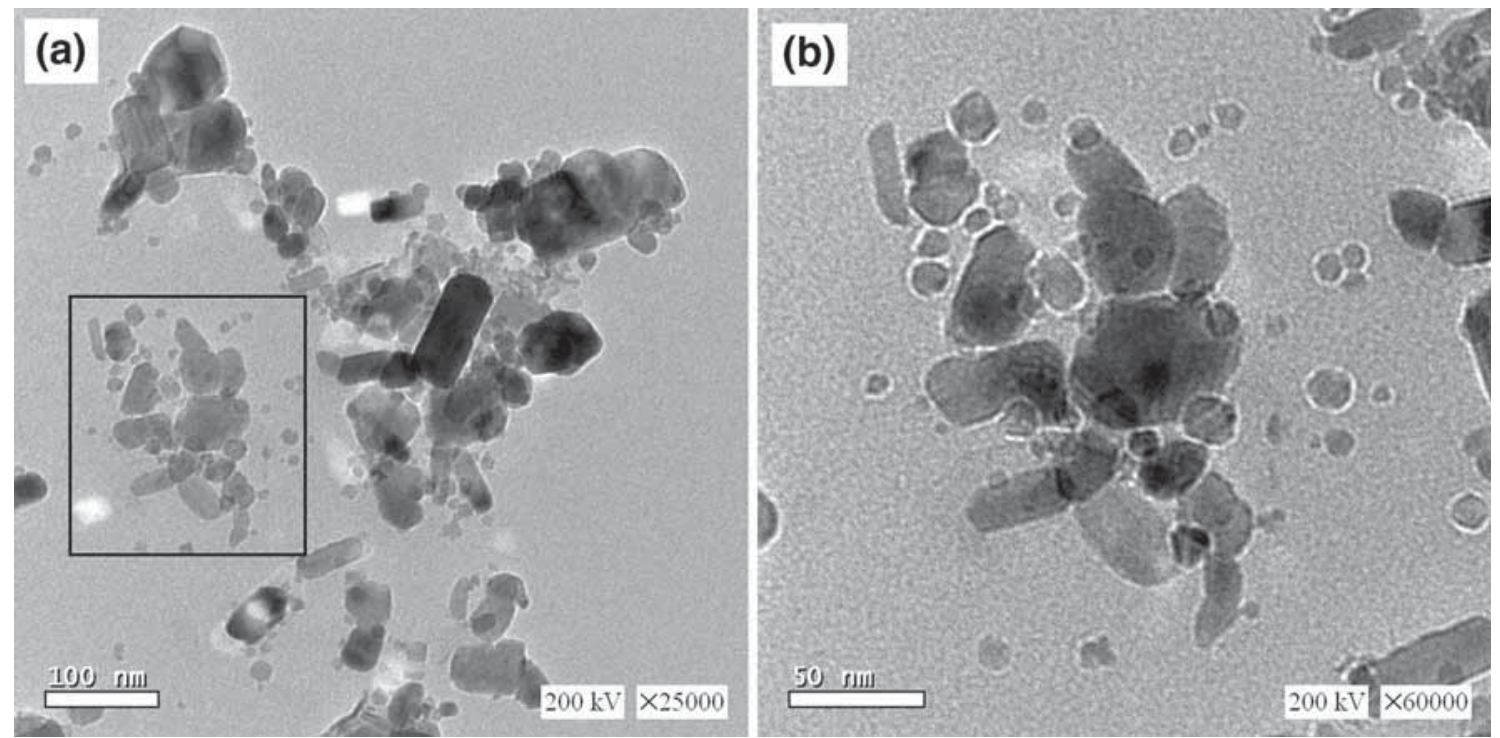

Figure 7. Typical TEM micrographs of nano-ZnO/grafted textile with different magnification power: (a) 25,000 and (b) 60,000.

Table 1. The antibacterial activity of nano- $\mathrm{ZnO} /$ grafted textile at different concentrations (\%) against some pathogenic bacteria.

\begin{tabular}{|c|c|c|c|c|}
\hline \multirow[b]{3}{*}{ Tested isolates } & \multicolumn{4}{|c|}{ Diameter of inhibition zone (mm) } \\
\hline & \multirow[b]{2}{*}{ Gentamycin } & \multicolumn{3}{|c|}{ Concentration of nano- $\mathrm{ZnO} /$ grafted textile $(\%)$} \\
\hline & & 0.05 & 0.3 & 3 \\
\hline Staph. spp. (1) & 15 & 9 & 10 & 15 \\
\hline Staph. spp. (2) & 20 & - & - & 10 \\
\hline Staph. spp. (3) & 22 & 9 & 9 & 9 \\
\hline Staph. spp. (4) & 22 & - & 9 & 10 \\
\hline Staph. spp. (5) & 21 & 9 & 10 & 13 \\
\hline E. $\operatorname{coli}(1)$ & 12 & 9 & 9 & 10 \\
\hline E. $\operatorname{coli}(2)$ & 13 & - & 8 & 8 \\
\hline E. $\operatorname{coli}(3)$ & 8 & - & 10 & 12 \\
\hline E. spp. (4) & - & 8 & 10 & 15 \\
\hline E. spp. (5) & - & - & 9 & 10 \\
\hline K. spp. (1) & 12 & 8 & 9 & 10 \\
\hline$K$. spp. (2) & 15 & - & 8 & 10 \\
\hline$K$. spp. (3) & 20 & 8 & 8 & 13 \\
\hline K. spp. (4) & - & - & 10 & 15 \\
\hline K. spp. (5) & - & - & - & 8 \\
\hline P. spp. (1) & 15 & - & 8 & 12 \\
\hline P. spp. (2) & - & - & - & - \\
\hline P. spp. (3) & 17 & 7 & 9 & 13 \\
\hline Bacillus sp. & 19 & - & - & 9 \\
\hline
\end{tabular}

brought about a drop in the degree of ordering of the plain textile and textile-g-(chitosan/HEMA). These findings were evidenced from the observed big drop in the relative intensity of the main diffraction line and its broadening [31]. The nano$\mathrm{ZnO} /$ grafted textile in figure $6 \mathrm{c}$ shows the peaks at 31.9, 34.6, $36.4,47.6,56.7,62.9,66.6,68.0$ and $69.2^{\circ}$, which can be assigned, respectively, to (100), (002), (101), (102), (110), (103), (200), (112) and (201) crystal planes of $\mathrm{ZnO}$ with hexagonal structure [32].

To determine the size and shape of the majority of $\mathrm{ZnO}$ NPs using the TEM, the particles in the grafted textile were crushed according to the procedure mentioned in the 


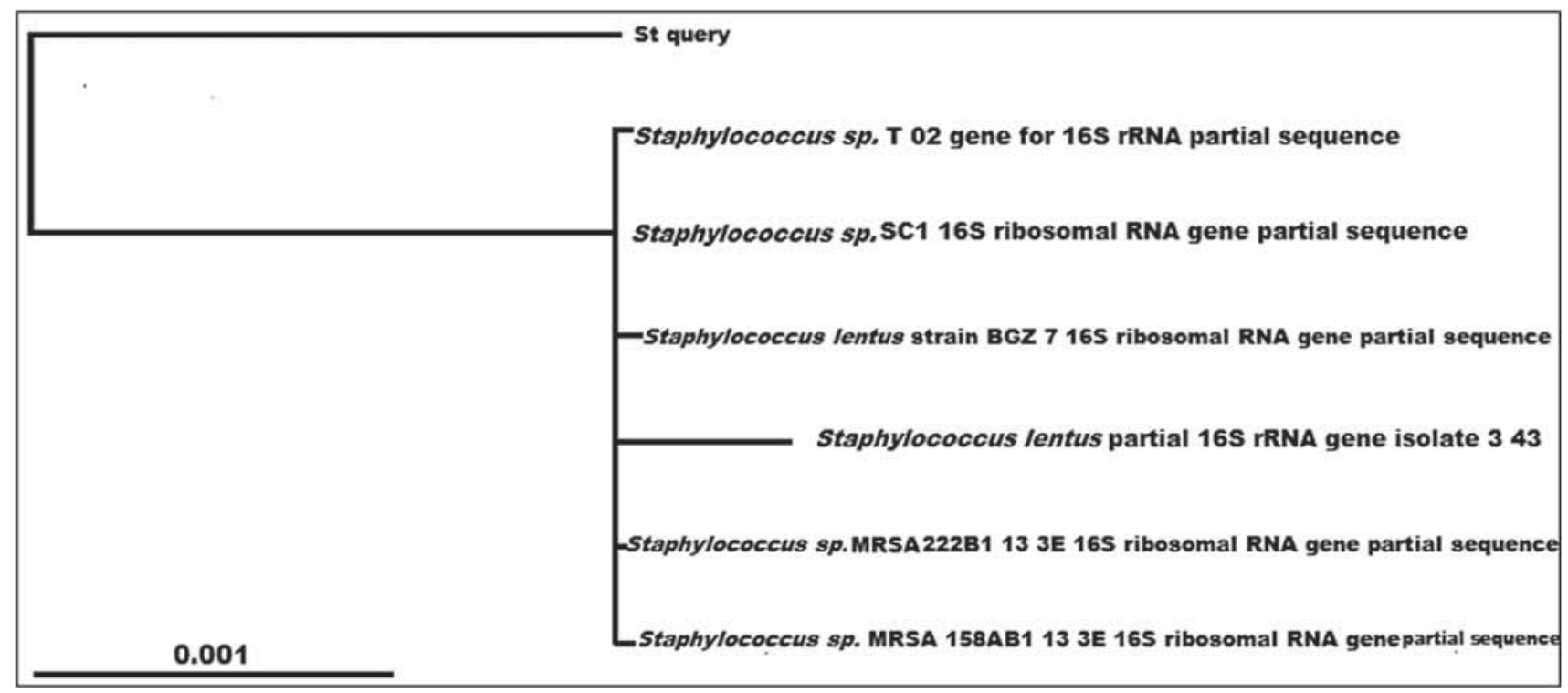

Figure 8. The phylogeny tree of Staphylococcus sp. PCR molecular identification.

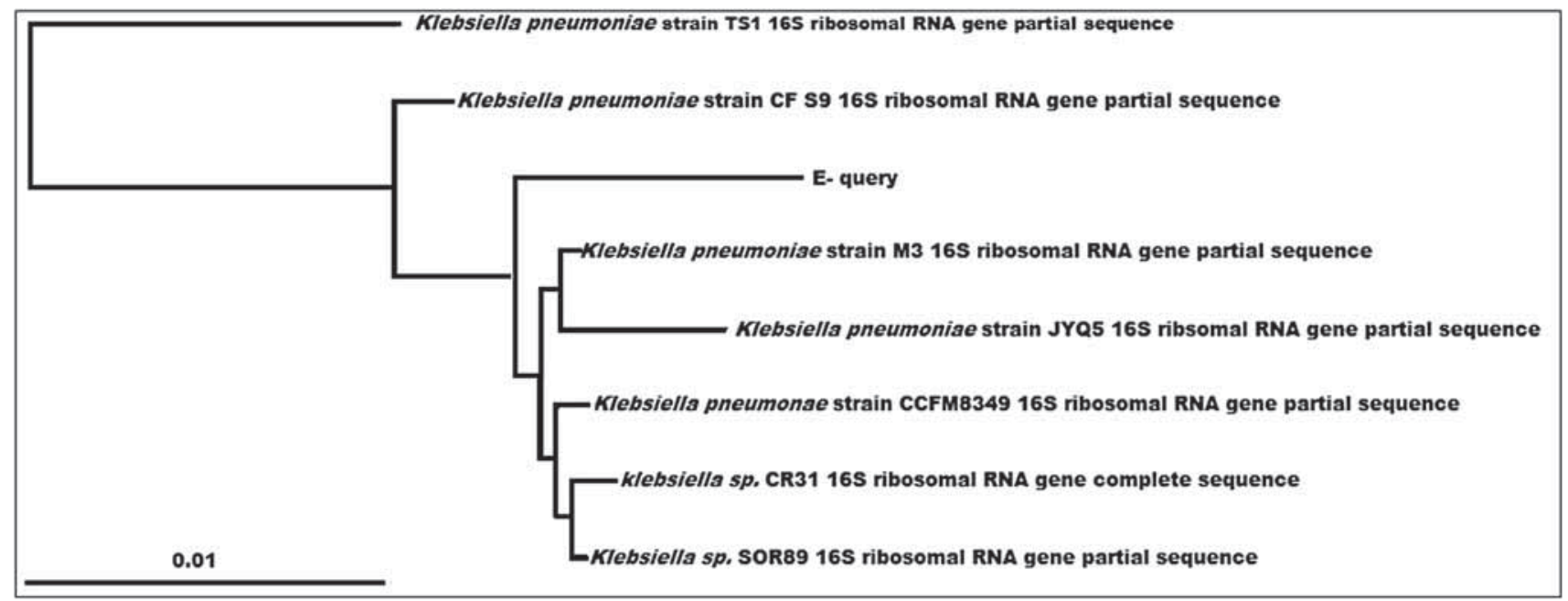

Figure 9. The phylogeny tree of Klebsiella pneumoniae PCR molecular identification.

experimental section and the supernatants were viewed under the TEM, which is presented in figure $7 \mathrm{a}$ and $\mathrm{b}$. It is clear from the figure that the $\mathrm{ZnO}$ NPs formed in the grafted textile are partially quasispherical in shape, highly dispersed and of small nanosize. The particles mean size is found to be $10 \mathrm{~nm}$ in the range $6.18-17.72 \mathrm{~nm}$.

\subsection{Applications}

3.3a Assessment of the antimicrobial activity of nanoZnO/grafted textile: The increase of the occurrence of antibiotic resistance in the pathogenic bacteria and fungi is a matter of serious concern. The antimicrobial property of new $\mathrm{ZnO}$-NPs has been found to be stable and of relatively low toxicity; hence, they are potential antimicrobial agents [7]. Consequently, one of the objectives of this study was to finish $\mathrm{ZnO}$-NPs onto the textile. The antimicrobial function of nano- $\mathrm{ZnO} /$ grafted textile was determined qualitatively by the disk diffusion method. Gentamycin and Nystatin, as two of the most active antibacterial and antifungal agents, were used as standards. On referring to them, nano- $\mathrm{ZnO} /$ grafted textile showed antimicrobial action against the tested pathogens at different levels (table 1), whereas the plain textile and chitosan/HEMA-g-textile showed no antimicrobial activity (not tabulated). As mentioned in the literatures, the antibacterial properties of chitosan are due to the interaction between the positive charges of chitosan and the electronegativity charged residues of the macromolecules at the microorganism cell surface, which causes the membrane leakage [33]. This 
antibacterial property has vanished due to the interaction of the positive amino groups of chitosan with negative hydroxyl groups of the HEMA during the grafting process. The tested pathogens showed an increasing inhibition zone with increasing $\mathrm{ZnO}-\mathrm{NP}$ concentrations. The results also showed that, on referring to the standard antibiotics, nano-ZnO/grafted textile $(3 \%)$ have a pronounced antimicrobial activity against Staphylococcus spp. (strain number 1) and Klebsiella spp. (strain number 4 ) with inhibition zone $(15 \mathrm{~mm})$ for both. Also, against Candida sp. the inhibition zone was $10 \mathrm{~mm}$, while it was not affected by Nystatin. The antimicrobial activity of nano-ZnO/grafted textile reported against MRSA and Klebsiella pneumoniae was 18.5 and $13.5 \mathrm{~mm}$ diameter inhibition zone, respectively, by Singh et al [34]. These results and that obtained by Rajendran et al [35] can be correlated with our results, where a significant antibacterial activity of fabrics treated with zinc oxide against MRSA is demonstrated. On the other hand, regarding the antimicrobial activity of the grafted discs, our results differ from others [36]; this difference may
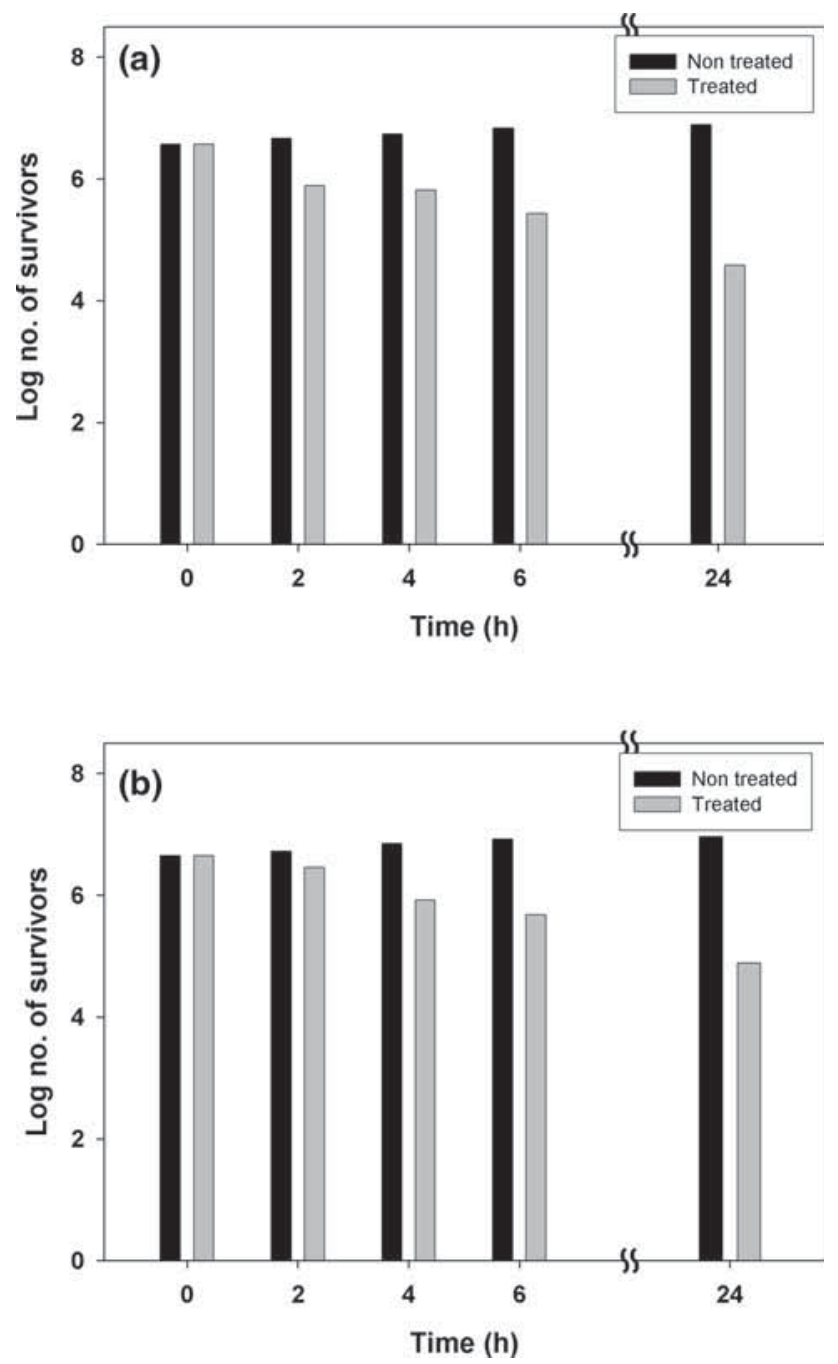

Figure 10. Effect of nano- $\mathrm{ZnO} /$ grafted textile (3\%) at different time intervals on (a) MRSA and (b) K. pneumoniae. be due to chemical modification of chitosan through the graft copolymerization.

Neighbour-joining phylogeny trees of the output result of BLAST indicated that the submitted gene corresponding to rRNA sequence is identical by $98 \%$ to Staphylococcus sp. MRSA222B1 13 3E 16S ribosomal RNA gene, partial sequence (figure 8 ) and by $97 \%$ to $K$. pneumoniae strain $\mathrm{CF}$ S9 16S ribosomal RNA gene, partial sequence (figure 9) [17].

Figure 10a and $\mathrm{b}$ shows the antibacterial action of nano$\mathrm{ZnO}$ /grafted textile quantitatively. The results indicated that, in case of plain textile the number of survivors of the applied strains increased during the 24-h contact time, while nano$\mathrm{ZnO} /$ grafted textile caused decrease in the log number of survivors of MRSA and K. pneumoniae by $2 \log$ cycles for both at the end of contact time. The antibacterial activity of $\mathrm{ZnO}$ NPs towards K. pneumoniae was studied by Brayner et al [37] and Sharma et al [38]; they observed that on contact with bacteria, the cytotoxic behaviour of ZnO NPs leads to rupture of the lipid bilayer of bacterium, resulting in leakage of cytoplasmic contents. Others suggested that this antimicrobial activity could be attributed to the generation of hydrogen

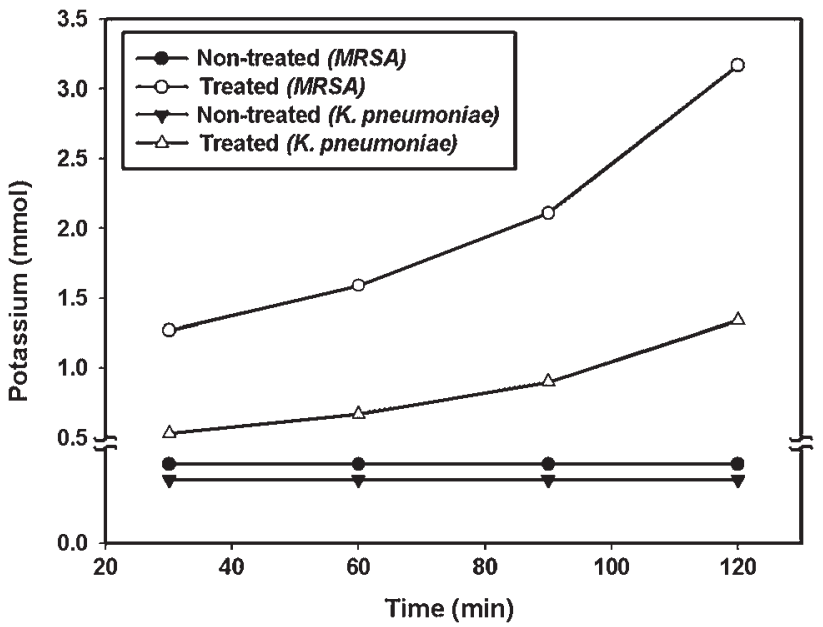

Figure 11. Effect of nano-ZnO/grafted textile on leakage of potassium ion from the tested strains for $120 \mathrm{~min}$ at $37^{\circ} \mathrm{C}$.

Table 2. Loss of 260-nm absorbing material.

\begin{tabular}{lccc}
\hline & \multicolumn{3}{c}{ Time (h) } \\
\cline { 2 - 4 } Treatment & 2 & 4 & 6 \\
\hline MRSA & & & \\
Control cells & 2.81 & 2.83 & 2.80 \\
Cells treated with plain textile discs & 2.80 & 2.81 & 2.81 \\
$\quad$ Cells treated with nano-ZnO/grafted & 3.97 & 4.52 & 4.99 \\
$\quad$ textile discs & & & \\
$K$. pneumoniae & & & \\
Control cells & 2.90 & 2.90 & 2.89 \\
Cells treated with plain textile discs & 2.87 & 2.87 & 2.85 \\
Cells treated with nano-ZnO/grafted & 3.60 & 4.08 & 4.72 \\
$\quad$ textile discs & & & \\
\hline
\end{tabular}




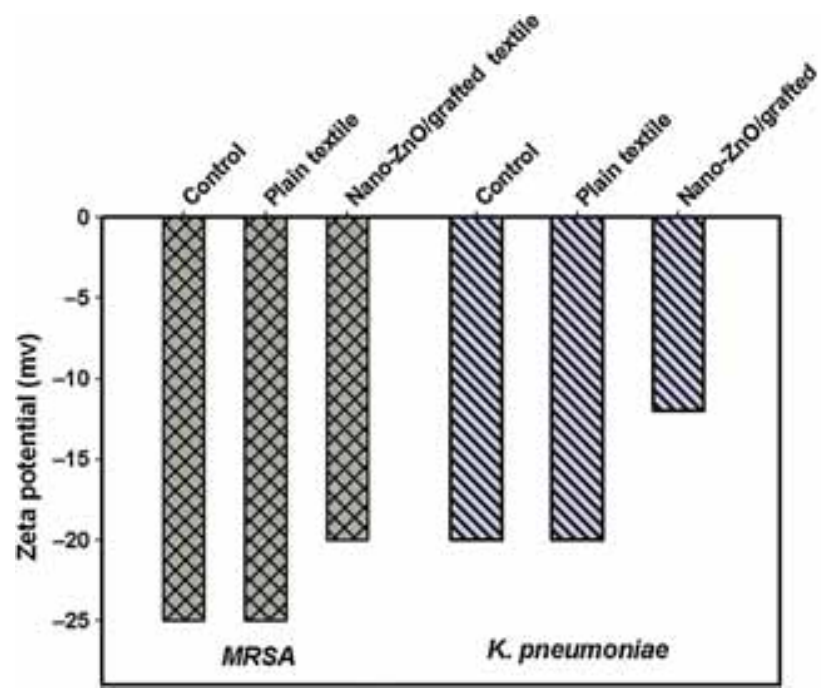

Figure 12. Bacterial surface charge-Zeta potential of tested strains treated with nano- $\mathrm{ZnO} /$ grafted textile.

peroxide from the surface of $\mathrm{ZnO}$, which is considered as an effective means for the inhibition of bacterial growth [39]. Several studies have proposed the release of $\mathrm{Zn}^{2+}$ ions, which can damage the cell membrane and interact with intracellular contents [37].

To investigate the mode of action of nano- $\mathrm{ZnO}$ against the susceptible strains, the following tests were carried out.

\section{$3.3 \mathrm{~b}$ Leakage of potassium ion and $260 \mathrm{~nm}$ absorbing mate-}

rial: The precise detection of potassium ion is crucial because it plays a leading role in membrane transport. Therefore, the effect of $\mathrm{ZnO}$ NPs on leakage of potassium from the selected strains is studied and shown in figure 11. The results indicated that no loss from cells treated by plain textile discs was noticed over all time intervals of the experiment, while in case of nano-ZnO/grafted textile discs, the loss of potassium ion increased with the evaluated intervals. Another strategy for determining the mode of action was based on the release of cell constituents determined by the measurements of absorbance at $260 \mathrm{~nm}$. The increase of ODs reading of the cells treated with $\mathrm{ZnO}-\mathrm{NP}$ discs, compared with that in case of plain discs (table 2), shows its ability to damage the cytoplasmic membrane, and $\mathrm{ZnO} \mathrm{NPs}$ rupture the lipid bilayer of bacterium, resulting in leakage of cytoplasmic contents [38].
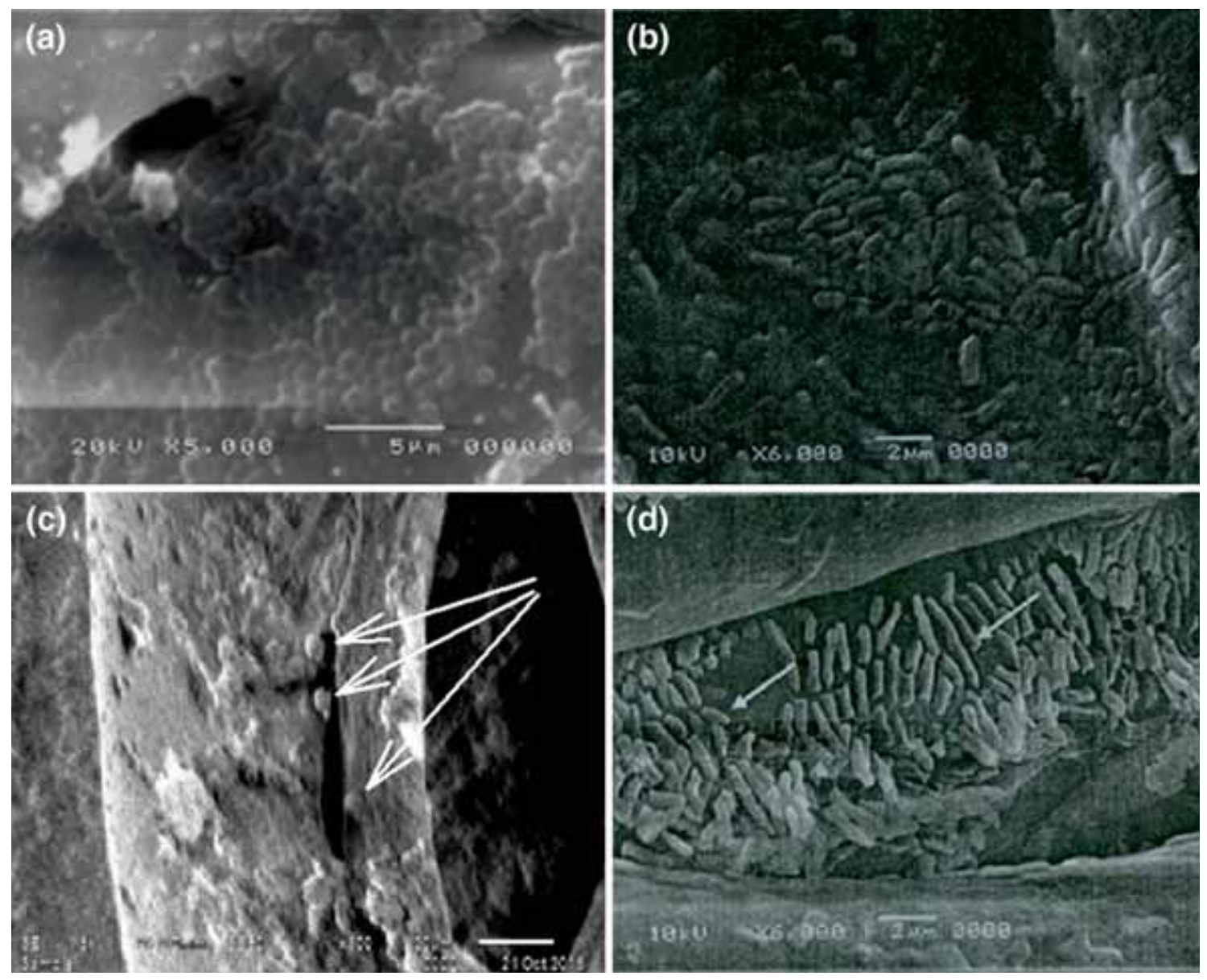

Figure 13. SEM images of MRSA and K. pneumonia grown on (a and $\mathbf{b})$ plain textile and ( $\mathbf{c}$ and $\mathbf{d}$ ) nano-ZnO/grafted textile. 
Zeta potential measurements are carried out to examine the effect of $\mathrm{ZnO}$ NPs on the membrane surface potential. As shown in figure 12 , the bacterial cells with plain textile discs display zeta potential of -25 and $-20 \mathrm{mV}$ for MRSA and $K$. pneumoniae, respectively. However the zeta potential decreased after contact with nano- $\mathrm{ZnO} /$ grafted textile discs. Our results are in agreement with another study performed by Arakha et al [40]. This emphasizes the capability of NPs to destabilize the bacterial membrane as a result of electrostatic interaction between nano- $\mathrm{ZnO} /$ grafted textile, which contain +ve charge in water suspension, and bacterial cell surface (negatively charged). Such reverse charges enhance the total effect by creating electrostatic forces, which serve as a powerful bond between ZnO NPs and bacterial surface, causing cell membrane damage $[7,41]$.

3.3c SEM study: Figure 13 (plates a and b) presents the morphology, respectively, of MRSA and K. pneumoniae grown on plain discs, with a huge number of cells observed by SEM. On the other hand, plates c and d show smaller number of deformed cells grown on nano-ZnO/grafted textile discs.

\section{Conclusion}

In this study, $\mathrm{ZnO}$ NPs were successfully stabilized in textileg-(chitosan/HEMA) by gamma radiation. The grafting and swelling percent are significantly influenced by the copolymer composition and irradiation dose. The EDX analysis confirms the existence of $\mathrm{Zn}$ and $\mathrm{O}$ peaks of $\mathrm{ZnO}$ in the grafted textile. The X-ray data confirm the crystal phase of ZnO NPs embedded in the grafted textile as a hexagonal structure. The TEM analysis proved that the ZnO NPs were well dispersed in the grafted textile with mean size of $10 \mathrm{~nm}$ in the range $6.18-17.72 \mathrm{~nm}$. The nano-ZnO/grafted textile with different $\mathrm{ZnO}$ concentrations was tested for its antimicrobial activity against 20 clinical isolates. The results revealed that nano$\mathrm{ZnO}$ /grafted textile (3\%) showed a pronounced antimicrobial action at different levels. The most susceptible isolates were identified genetically as $16 \mathrm{~S}$ rRNA of MRSA and K. pneumoniae. The number of survivors of the two strains decreased by two log cycles during $24 \mathrm{~h}$ contact time. Loss of potassium ion and release of cell constituents at $260 \mathrm{~nm}$, observed in case of nano- $\mathrm{ZnO}$ /grafted textile, and decrease of membrane surface potential, determined by measurements of zeta potential, demonstrate its ability to damage the cytoplasmic membrane. The SEM examination of cells grown on nano- $\mathrm{ZnO} /$ textile showed a decrease in the number of cells with deformation in the cells. These results are promising in the antimicrobial field.

\section{References}

[1] Tinker K 2010 Moment of truth: proper air flow critical to healthcare laundries $A$ white paper from the Healthcare Laundry Accreditation Council
[2] Rattanawaleedirojin P, Saengiettiyut K and Sangsuk S 2008 J. Nat. Sci. 775

[3] Gupta P, Bajpai M and Bajpai S K 2008 J. Cotton Sci. 12280

[4] Vinosova J and Vavrikova E 2008 Curr. Pharm. Des. 14 1311

[5] Fu L, Liu Z, Liu Y, Hu P, Cao L and Zhu D 2005 Adv. Mater. 17 217

[6] Makhluf S, Dror R, Nitzan Y, Abramovich Y, Jelnek R and Gedanken A 2005 Adv. Funct. Mater. 151708

[7] Stoimenov P K, Klinger R L, Marchin G L and Klabunde K J 2002 Langmuir 186679

[8] Holister P, Weener J W, Vas C R and Harper T 2003 Nanoparticles: technology white papers 3 (London: Cientific Ltd.)

[9] Martinez-Gutierrez F, Olive P L, Banuelos A, Orrantia E, Nino N, Sanchez E M et al 2010 Nanomedicine 6681

[10] Gao Y and Cranston R 2008 Text. Res. J. 7860

[11] Chen C Y and Chiang C L 2008 Mater. Lett. 623607

[12] Duran N, Marcarto P D, De Souza G I H, Alves O L and Esposito E 2007 J. Biomed. Nanotechnol. 3203

[13] Sawai J, Kawada E, Kanou F, Igarashi H, Hashimoto A, Kokugan T et al 1996 J. Chem. Eng. Jpn. 29627

[14] Huang Z, Zheng X, Yan D, Yin G, Liao X, Kang Y et al 2008 Langmuir 244140

[15] Zhang L, Jiang Y, Ding Y et al 2007 J. Nanopart. Res. 9479

[16] Ophori E A and Wemabu E C 2010 Nigeria. Afr. J. Microbiol. Res. 41719

[17] James G 2010 In: M Schuller, T P Sloots, G S James, C L Halliday and I W J Carter (eds) PCR for clinical microbiology ISBN: 978-90-481-9038-6 (Netherlands: Springer) p 209

[18] AATCC Committee RA31 1961 Antibacterial finishes on textile materials: assessment of AATCC Test Method 100-2004 developed in 1961

[19] Eid M and Araby E 2013 Appl. Biochem. Biotechnol. 171 469

[20] Halder S, Yadava K K, Sarkar R, Mukherjee S, Saha P, Halder S et al 2015 Springerplus 4672

[21] Ali A E H, Shawky H A, El Rehim H A A and Hegazy E A 2003 Eur. Polym. J. 392337

[22] Taher N H, Dessouki A M and El-Arnaouty M B 1998 Radiat. Phys. Chem. 53437

[23] El-Arnaouty M B, El-Kelesh N A and Abdel-Aal S E 2004 Arab. J. Nucl. Sci. Appl. 3717

[24] El-Arnaouty M B, Abedel Ghaffar A M and El-Shafey H M 2008 J. Appl. Polym. Sci. 107744

[25] Taher N H, El-Sayed A H, Dessouki A M and El-Arnaouty M B 1989 Int. J. Radiat. Appl. Instrum. C Radiat. Phys. Chem. 33 129

[26] El-Hag A A and Al-Arifi A 2009 Carbohydr. Polym. 78 725

[27] Lanthong P, Nuish R and Kiatkamjornwong S 2006 Carbohydr. Polym. 66229

[28] Fang J M, Fowler P A, Sayers C and Williams P A 2004 Carbohydr. Polym. 55283

[29] Wang P, Wu X, Xue D, Xu K, Tan Y, Du X and Li W 2009 Carbohydr. Res. 344851

[30] Fan L, Luo C, Zhen L, Fuguang L and Qiu H 2011 Colloids Surf. B Biointerfaces $\mathbf{8 8} 574$

[31] Atia K S, Al-Arnaouty M B, Ismail S A and Dessouki A M 2003 J. Appl. Polym. Sci. 90155

[32] Salehi R, Arami M, Mahmodi N M, Bahrami H and Kharramfor S 2010 Colloid Surf. B 8086 
[33] Begin A and Van Calsteren M R 1999 Int. J. Biol. Macromol. 26 63

[34] Singh G, Joyce M E, Beddow J and Mason J T 2012 J. Microbiol. Biotechnol. Food Sci. 2106

[35] Rajendram R, Balakumar C, Ahammed M A H, Jaya Kumar S, Vaideki K and Rajesh E M 2010 Int. J. Eng. Sci. Technol. 2 202

[36] Ignatova M, Manolova N and Rashkov I 2007 Eur. Polym. J. 43 1112
[37] Brayner R, Ferrari-Iliou R, Brivois N, Djediat S, Benedetti M $\mathrm{F}$ and Fievet F 2006 Nano Lett. 6866

[38] Sharma D, Rajput J, Kaith B S, Kaur M and Sharma S 2010 Thin Solid Films 5191224

[39] Yamamoto O 2001 Int. J. Inorg. Mater. 3643

[40] Arakha M, Saleem M, Mallick C B and Jha S 2015 Scientific Rep. 59578

[41] Zhang L, Ding Y, Povey M and York D 2008 Prog. Nat. Sci. 18 939 